\title{
The Influence of Corporate Social Responsibility (CSR) Activities on Consumers' Purchasing Behavior
}

\author{
(Pengaruh Aktiviti Tanggungjawab Sosial Korporat (CSR) terhadap Kelakuan Pembeli
} Pengguna)

\author{
Boon Heng Teh \\ (Faculty of Management, Multimedia University) \\ Tze San Ong \\ Lai Teng Pang \\ Haslinah Muhammad \\ (Faculty of Economics and Management, Universiti Putra Malaysia) \\ Tze Chin Ong \\ (Inti International University)
}

\begin{abstract}
The purpose of this paper is to examine the influence of Corporate Social Responsibility (CSR) activities, which include economic, environmental, social, and legal concerns on consumers' purchasing behavior in the Malaysian context. A questionnaire was developed to collect data from the respondents using snowballing sampling. This research found mixed results in term of significance of the relationships between economic, social, and legal concerns and consumers' purchasing behavior. Environmental concerns had an insignificant relationship with consumers' purchasing behavior. The results of this research may help managers in managing their businesses, since a single CSR strategy cannot be competitive for corporations to participate in the current global business environment. The findings may be useful to policymakers as it encourages corporations to engage actively in CSR. The outcome of this research may expand the knowledge base on CSR, since most of the investigations on consumers' responses to CSR have been limited to a few states in Malaysia.
\end{abstract}

Keywords: Corporate social responsibility; consumers' purchasing behavior; economic concerns; environmental concerns; social concerns and legal concerns.

\section{ABSTRAK}

Tujuan makalah ini adalah untuk mengkaji pengaruh kegiatan tanggungjawab sosial korporat (CSR) yang meliputi kebimbangan ekonomi, kebimbangan alam sekitar, kebimbangan sosial dan kebimbangan undang-undang terhadap tingkah laku pembelian pengguna dalam konteks Malaysia. Soal selidik telah dibangunkan untuk mengumpulkan data daripada responden dan pensampelan snowballing telah digunakan. Penyelidikan ini mendapati keputusan bercampur di mana kebimbangan ekonomi, kebimbangan sosial dan kebimbangan undang-undang mempunyai hubungan yang ketara terhadap tingkah laku pembelian pengguna. Sebaliknya, kebimbangan alam sekitar mempunyai hubungan yang tidak penting terhadap tingkah laku pembelian pengguna. Hasil penyelidikan ini berguna kepada pengurus dalam menguruskan perniagaan mereka kerana satu strategi CSR tunggal tidak boleh berdaya saing untuk syarikatsyarikat untuk mengambil bahagian dalam persekitaran perniagaan global yang dinamis ini. Penemuan ini juga berguna kepada pembuat dasar kerana kajian ini mencadangkan peluang penting untuk menggalakkan syarikat-syarikat perniagaan untuk terlibat dan mendedahkan CSR. Hasil kajian ini dijangka dapat mengembangkan asas pengetahuan di kawasan CSR di 
mana kebanyakan penyiasatan terhadap tindak balas pengguna telah terhad kepada beberapa negeri di Malaysia.

Kata kunci: Tanggungjawab sosial korporat; kebimbangan ekonomi; kebimbangan alam sekitar; kebimbangan social; kebimbangan undang-undang

\section{INTRODUCTION}

Generally, Corporate Social Responsibility (CSR) is the continuing commitment by a business to serve its stakeholders such as customers, suppliers, investors, regulators, and the public, rather than focusing on only managing the shareholders. Liz Max, the Chief Executive Officer of the nonprofit organization Net Impact, noted that CSR practices are becoming more mainstream as companies are looking to drive sustainability and their core business to create shared value for businesses and the society (Fallon 2014). Therefore, companies should not only be profitable tools, but also be socially responsible. Hence, a proper implementation of CSR can bring about competitive advantage to companies (Patil \& Sawant 2014).

The term "corporate social responsibility" became popular in the 1960s and the concept has evolved over time. In the 1970s, Carroll's 4-part concept of economic, legal, ethical and philanthropic responsibilities - later illustrated as a CSR pyramid - was the first broadly accepted definition of CSR. In the 1980s, CSR started to be applied to quality management in occupational health and safety and introduced as CSR codes like Responsible Care. As time passed, CSR established standards such as ISO 14001 and SA 8000, guidelines such as Global Reporting Initiatives, and corporate governance codes such as Cadbury and King in the 1990s. Later, in the 21 st century, additional CSR guidelines, codes and standards were introduced, incorporating new themes like industry sector and climate change. In addition, CSR 1.0 started to move beyond the outdated approach of philanthropy to a more interactive, stakeholder driven model. This is because of the limitations of the CSR codes and standards that have increased over the past 10 years. Going forward, CSR 2.0 might include five doctrines making up a new (DNA of CSR 2.0 - namely connectedness, scalability, responsiveness, duality and circularity (Visser 2011). The essence of CSR 2.0 is for it to be transformational and offer practical strategies to sustain long-term capitalism.

In Malaysia, the "The Australian Stop Lynas campaign" is an environmental issue, which started in March 2011, saw thousands of Malaysians uniting to say "No" to the Australian rare earth miner, Lynas Corporation. This was the first time that a large number of Malaysians protested on an environmental issue involving the Lynas Advanced Materials Plant (LAMP) a rare earth processing plant operating in Kuantan, Malaysia - dumping tons of toxic and radioactive waste on their land; thus, affecting the health of future generations. The citizens who protested demanded a clean and safer environment. Due to the protest against the project, Star Online reported that the shares of the Lynas Corporation hit a five-year low. These results implied that the brand image and reputation of Lynas Corporation might have been affected by these campaigns and led to the fall in the share price. Most companies in Malaysia seem to view the practice of CSR as costly as they would have to allocate substantial amount of time and resources to perform CSR activities. Most companies view their returns based on the short term as opposed to the long-term benefit or returns of CSR. This implies that most companies are sensitive to the level of consumer demand and their consumers' purchasing behavior.

Based on the above, this research aims to investigate the influence of CSR activities on consumers' purchasing behavior in the Malaysian context. Firstly, this study contributes to the understanding of CSR as it discusses the definitions and evolution of CSR later in this study. Secondly, this research explores whether Malaysian consumers consider a companies' CSR 
practices before they make their purchase decisions. Finally, this study examines the various dimensions of CSR that influence consumers' purchasing behavior.

\section{LITERATURE REVIEW}

\section{CSR ACTIVITIES AND CONSUMERS' PURCHASING BEHAVIOR}

Institutional theory explains how a company appropriate action, leads to the company making a right decision. Institutional theory recommends that an organization follow the constituents' pressures in organizational areas such as compliance to the rules and regulations of its institutional atmosphere (Dimaggio \& Powell 1983). This affects how organizations make decisions by providing insights into their role in CSR activities. Institutional theory also implies that practices and policies of organizations react to social and institutional pressures exerted by influential stakeholders groups in order to comply with prevailing societal expectations to advance, sustain or repair legitimacy and help in understanding why organizations are affected by CSR activities.

Apart from institutional theory, stakeholder theory is also used in this study. Stakeholders control the critical resources and whom the organizations depend on to influence corporate performance (Freeman, 1984). External stakeholder groups can have positions that diverge from the organizations' agenda particularly concerning CSR activities. Stakeholder theory states that organizations have social responsibilities and managers have moral responsibilities towards stakeholders besides financial returns (Hendry 2001). Thus, stakeholders' pressure is important for the development of CSR activities (Safi \& Ramay 2013; Ong, Teh \& Ang 2014).

Several researchers have suggested that there are positive relationships between a company's CSR activities and consumers' behavior towards the company and its products or services (e.g. Rahim, Jalaludin \& Tajuddin 2011; Safi \& Ramay 2013; Vahdati, Mousavi \& Tajik 2015). Safi and Ramay (2013) stated that there were significant relationships between CSR activities and their consumers' purchasing behavior. Sen, Bhattacharya and Korschun (2006) and Scholder, Webb and Mohr (2006) studied US firms and found that CSR positively influenced both consumers' purchase intent and their perceptions of companies' products.

Pomering and Dolnica (2009) stated that the expectations of consumers towards companies provide information about what companies do, and in turn, the consumers will support companies with CSR initiatives. Rahim et al. (2011) concluded that society has become more proprietary and there is greater awareness of CSR among consumers. Butt (2016) conducted three in-depth interviews and three focus groups to understand consumer-buying behavior towards organizations involved in CSR activities, found that the consumers from lower income group were mainly concerned with price and did not care much about the CSR initiatives of companies.

Meanwhile, researchers have differing perceptions over from the importance of CSR activities across countries. Maignan (2001) conducted a research in Germany and France, and argued that respondents placed legal concerns as their most important responsibility, followed by ethical, philanthropic and economic responsibility - which was vastly different from Carroll's CSR pyramid. Visser (2005) stated that consumers in Africa valued economic responsibility the most followed by philanthropic responsibility, and then by legal and ethical responsibility. Different countries have differing perceptions on the importance of companies' CSR activities, which inevitably influences consumers' buying behavior.

Many researchers have investigated the relationship between CSR dimensions and consumers' purchasing behavior. Most found that there are positive relationships between companies' CSR activities and consumers' buying behavior (Nochai \& Nochai 2014; Amran $\&$ Nejati 2014). Results show that nearly half of the respondents in their survey agreed that 
they would avoid purchasing products from irresponsible companies (Zhao 2012). Boccia, Malgeri Manzo and Covino (2018) compared socially responsible initiatives weightage of the companies with the presence or absence of a renowned brand. From market analysis and the information obtained from literature reviews, showed that in recent years, demand dynamics are closely related to the presence of more observant and conscious consumers of businesses' ethical dimensions. Due to the presence of consumers' consciousness, there is a growing demand for companies to commit to greater social and environmental responsibility (Boccia et al. 2018). CSR is expected to be fair to customers, leading to higher satisfaction. Lastly, reputation is a general attribute of firms and reflects the extent to which a firm is perceived as good or bad (Roberts \& Dowling 2002). CSR signals to stakeholders a positive ideal of corporate behavior, thereby increasing reputation.

\section{ECONOMIC CONCERNS}

In the traditional view of business, many companies focus solely on profit generating activities. However, in today's dynamic business world, it is difficult to focus solely on short-term strategies like profits or on shareholders' wealth to sustain companies without paying attention to the society, the environment and other stakeholders. If companies want to sustain their performance in the future, they should not only be concerned about financial benefits, but should also be concerned for the society and the environment. Carroll (1991) stated that economic responsibility entails that an organization must perform its basic responsibility such as providing goods and services that society wants at reasonable prices while at the same time generating financial returns.

McAlister, Ferrell and Ferrell (2003) also supported this view and they agreed that the economy is affected by how companies relate to the stakeholders. Economic responsibilities lie in maximizing not only shareholders' interests, but also stakeholders' interest. Dusuki and Yusof (2008) conducted the survey of 457 respondents in Malaysia, and argued that economic responsibility is the most basic and vital responsibility as compared to other responsibilities. Companies must first be able to meet their economic responsibilities before they can perform or engage in other responsibilities or CSR activities such as charity events or donations.

Nonetheless, other researchers have argued on the prime importance of economic responsibility. Safi and Ramay (2013) stated that socially responsible organizations with poor economic performance are at risk based on an empirical study of 313 responses across Pakistan. Companies experiencing losses who continue with their CSR activities by giving donations may face financial difficulties like higher debts. Companies should also consider their financial ability when practicing CSR.

Onlaor and Rotchanalitumnuai (2010) revealed that one of the most important factors that influences consumer satisfaction and buying behavior is the price based on the findings from a survey of 400 mobile customers in Thailand. Consumers may feel unsatisfied with goods and services when offered at an unreasonably high price that makes them unaffordable. Hence, the purchasing behavior as well as consumer loyalty to the companies' products and services is affected as well. Paco, Raposo and Filho (2009) showed that consumers are more concerned over economic factors. They used a self-administered questionnaire survey as the mode for data collection. A group of 55 interviewers (university students) distributed the questionnaires in their cities of origin to Portuguese consumers sampled. The results showed that Portuguese consumers' are concerned about protecting the environment by saving electricity and water, although these concerns maybe more closely related with economic factors than with environmental consciousness. 
Studies on consumers' environmental-economics friendly behavior and attitudes towards green products have gained prominence in emerging economies (Khare 2015). Stakeholder theory is concerned about the nature of stakeholders' associations with the company and acknowledges the importance of stakeholders in managerial decision-making (Frooman 1999). Businesses are trying to identify the economic interest of their stakeholders, this would influence the company, and how management is prioritizing them. In this current study, the profitability of the companies seems to relate to economic responsibilities. The profits that the companies earn maybe used to meet their economic responsibilities towards their consumers. Most of the previous researchers have found that there are positive relationships between economic activities and consumers' purchasing behavior (Rahim et al. 2011; Safi \& Ramay 2013; Forsman-Hugg et al. 2013; Gallardo-Vázquez \& Sanchez-Hernandez 2014). Based on the stakeholder theory and past studies, this study proposes the following hypothesis:

$\mathrm{H}_{1 \mathrm{a}}$ There is a positive relationship between economic concerns and consumers' purchasing behavior.

\section{ENVIRONMENTAL CONCERNS}

Haytko and Matulich (2008); Vermillion and Peart (2010); Leonidou and Leonidou (2011) stated that environmental concerns may influence a company's approach to CSR. This issue has received much attention in the media and in the marketing literature in recent decades. The environmental dimension of CSR refers to how business operations are concerned about the natural environment and take action to protect the environment.

In the past few decades, researches have shown that many companies have or already started to pay more attention to the concept of sustainability. Companies are more aware of the need to reduce their environmental footprint (Gadenne et al. 2011). In recent years, information concerning the environment and climate change has had an impact on the daily behavior of consumers.

The findings from the survey of 259 consumers in a major metropolitan area in the Southeastern United States showed that from the customers' perspective, their environmental concerns involve activities such as recycling, implementing energy-saving measures and reducing pollution (Parsa et al. 2015). Other activities include using "green" production practices such as reducing greenhouse emissions, using recycled containers, reducing the quantity of plastic packaging materials and sourcing materials from vendors located geographically close to the manufacturing facilities. Van Birgelen et al. (2009) stated that some companies implement their environmental responsibilities by attaching eco-friendly labels to their products as a way of advertising their environmental friendly efforts to their consumers based on an online survey of 176 German respondents.

By examining the literature, there is an argument that greater cost is involved when being socially responsible. A significant amount of money is spent purchasing new environmental friendly equipment, changing management structure and implementing strict quality controls (Wong, Lee \& Sun 2012). CSR must not conflict with this goal, as the main goal of companies is to generate profits (Kaika \& Zervas 2013; Khojastehpour \& Johns 2014; Sun 2012; Thompson \& Ke 2012).

Rahbar and Wahid (2010) explored how consumers' attitude toward environmental protection and knowledge may affect their actual purchase behavior using a convenient sample of 250 consumers in Penang, Malaysia. The study collected data via a structured questionnaire survey distributed in three Penang shopping centers where people buy their daily necessities (mall intercept). The results indicate that consumer attitudes toward environmental protection comprise three components: individual responsibility in environmental protection, government 
and industries roles, and financial roles. Of these components, attitude toward the role of government and industry and attitude towards financial role in environmental protection have positive and significant impacts on consumers' actual purchase behavior, but the impact of environmental knowledge is not significant.

Most of the previous studies showed that the implementation of environmental practices benefits both the stakeholders and companies themselves. However, Al-Dmour and Askar (2011) argued that the benefit of CSR exceeds its cost. One of the examples that illustrates that the benefit of CSR exceeds its cost is that, most housing contractors plant trees on sidewalks and in front of houses after completing construction in a particular area, as it is their environmental responsibility to the community. By doing so, it has a positive impact on the environment, adding financial value to the company as well as the property. Tree Preservation Organization (n.d.) stated that trees have the ability to add $15 \%$ to $20 \%$ value to a property. They also showed that children raised in areas with trees live healthier and happier lives benefits that money cannot buy. However, if the contractors neglect the replanting the trees, their reputation might be affected. This may damage the scenery of the housing area and may reduce the property value. Consumers also view environmentally responsible companies in a positive way and they are more likely to consider purchasing from these companies.

Institutional theory can explain the impact of being environmentally responsible on consumers' purchasing behavior. It explains the pressures exerted on organizations' environmental practices and responsibility related to climate change (Dimaggio \& Powell 1983). It shows how organizations make decisions by providing insights into their role in mitigating or reducing their environmental footprint and in achieving conformity. Thus, this study proposed the following hypothesis:

$\mathrm{H}_{1 b}$ There is a positive relationship between environmental concerns and consumers' purchasing behavior in Malaysia.

\section{SOCIAL CONCERNS}

Elkington (1997) stated that social capital refers to peoples' trust in the society. It can measure the ability of people to work together in a company. These capabilities are important to develop sustainability in every society. Turker (2009) said that CSR with respect to society refers to any activity that contributes to societal well-being. Many companies are seen to be more progressively and dynamic when focusing on the social concerns. This is a good sign that companies have started to involve themselves in the implementation of CSR activities in the society.

Social responsibilities mean being accountable for the social effects on society, whether directly or indirectly. Uddin, Hassan and Tarique (2008) stated that these include the people in the company, production employees, management staffs, customers, and other stakeholders in the company. From literature, social responsibilities also refer to the management's obligation to make choices and take actions that contribute to the welfare and interest of the society.

Three main key social aspects, namely consumers, employees and community, found in the literature relates to consumer purchasing behaviors (Uddin et al. 2008). Responsibilities towards the customers simply mean the idea of treating your customers with respect and attention. This entails producing safe and durable products and services, ensuring adequate supply of products and services, providing full and clear information, giving quick and considerate attention to customers' feedback and after sales services are some of these responsibilities. By doing so, a company may generate better consumer perception and increase its sales. 
Being responsible towards the community is another key social aspect. In general, the operations of companies typically depend on the health, stability and prosperity of the communities (Grimmer \& Bingham 2013; Moslehpour, Van Kien \& Danyfisla 2014). Carroll (1991) stated that it is important for managers and employees to participate in voluntary and charitable activities within their local communities, especially in projects that enhance a community's quality of life. These social activities might not benefit companies financially, but it can help create and build up the image or reputation of the companies and enhance the firms' long-term competitive position in the market (Rahim et al. 2011).

Grimmer and Bingham (2013) showed higher purchase intention for products from socially responsible companies based on an empirical study of 698 responses from Hobart, the capital of Tasmania, Australia. A survey of 415 responses from Indonesia and Taiwan also provided empirical evidences that positive attitudes toward societal factors could lead to positive attitudes and knowledge with respect to purchasing decision and buying frequency. Hence, the reputation of a company is crucial if the company is to sustain itself in today's business world. Many companies have been socially responsible by providing additional vacation training places, recruiting people with disabilities, sponsoring cultural events and giving donations to charitable entities. Researches have shown that stakeholders who are aware of a company's CSR activities reacted positively by purchasing its goods and services (Sen et al. 2006; Gatti, Caruana \& Snehota, 2012).

Corporate social responsibilities that relate to the society simply mean the responsibility of companies towards the society. Corporate respondents state that the major emphasis of social concerns is to give back to the society by providing social projects for people in need, such as the poor, disabled, unemployed and the sick. Some of the most popular social responsibilities that companies engage in are by providing financial and product charity donations as well as corporate volunteering. Companies also fulfill their social responsibilities in other areas by supporting the arts, young artists, cultural events and museums. Murphy, Öberseder and Laczniak (2014) stated that companies are not only supporting people with financial needs, but also protecting and fostering cultural heritage - which is a desirable CSR activity. For example, some companies support schools, universities, and sports teams for disabled people as contribution towards reducing societal problems (Miragaia et al. 2015). Most of the literature showed that social responsibilities have a positive impact on consumers' purchasing behavior. Consumers take into consideration the social activities that a company has engaged in when making purchase decisions. Therefore, companies should engage in more social activities in order to influence consumers' purchasing behavior (Lee \& Lee 2015).

In institutional theory, organizations follow the constituents' pressures, which also include societal and cultural practices within the organizations. External pressures also influence companies' strategies and decision-making particularly in CSR activities. The theory explains social responsibilities and there are findings that show a positive relationship linking social responsibilities and the brand preference of products thus influencing the purchasing behavior of consumers (Gupta 2012; Liu et al. 2014). Thus, this study proposes the following hypothesis:

$\mathrm{H}_{1} \mathrm{c}$ There is a positive relationship between social concerns and the consumers' purchasing behavior.

\section{LEGAL CONCERNS}

Carroll (1991) defined legal responsibilities as a company's compliance with laws and regulationss when making business decisions. While companies create profit for their shareholders, they operate under the legal system and regulations. Companies work within the context of laws and regulations as a partial fulfillment of the "social contract" between the 
companies and the society when they are carrying out their legal responsibilities (Rahim et al. 2011). Rahim et al. (2011) showed that legal responsibility is positively and significantly associated with consumer purchasing behavior based on a survey involving 193 Malaysian respondents. Maignan (2001) stated that legal concerns affected consumer-purchasing behavior in Germany and France. As a result, it is important to observe legal responsibilities in a manner that is consistent with the expectations of governments and laws, and conform to various federal, state and local regulations. Although laws are important, they are often inadequate.

Carroll's CSR pyramid shows that laws cannot possibly address all of the issues faced by a company. Laws usually lag behind recent concepts deemed as right behavior. Laws also may represent the personal interests and political motivations of its legislators. The purpose of legal responsibility is to ensure that the companies' activities and performances are acceptable to the stakeholders. A successful corporation must fulfill its legal obligations. The consumer expects the companies to meet the legal requirement in terms of product safety, quality, and accurate information. Failing to comply with these aspects, may adversely affect companies' performance (Carroll 2016).

Consumers expect companies to meet the legal requirements for product quality, product safety, and the accuracy of information about the products. For example, Malaysia has the SIRIM certification (Standards and Industrial Research Institute of Malaysia) which recognizes the quality and innovativeness for Malaysian products and services worldwide. If a company meets the requirements, consumers will feel safe to buy products from the company. If the company fails to comply with their legal responsibilities, the company's performance may be affected. Thus, a successful company must fulfill its legal obligations in order to attract more customers to purchase its products, and to repeat the purchase.

Institutional theory is concerned with organizational ability to comply with rules and regulations that exert conformance pressures and standards in the institutional environment (Dimaggio \& Powel 1983). It also implies that external pressures influence companies' strategies and decision-making to implement practices ensuring legitimacy or to legitimize their practices. The theory supports legal responsibilities and researchers have shown a relationship exist between legal concerns and consumers' purchasing behavior. Compliance with consumer protection laws and customer protection laws are positively associated with satisfaction and loyalty, which in turn influence the consumers' purchasing behavior (McDonald \& Thiele 2008; Galbreath 2010; Islam 2015). Therefore, the study proposes the following hypothesis:

$\mathrm{H}_{1 \mathrm{~d}}$ There is a positive relationship between legal concerns and the consumers' purchasing behavior.

\section{METHODOLOGY}

\section{SAMPLE AND PROCEDURE}

The snowball sampling method was used due to its relevance in industrial buyer-seller studies to determine the buyer-seller pairs, with the benefit of low sampling costs and variances (Malhotra \& Dash 2011). A thousand questionnaires were distributed through online and social media to the initial group of respondents who were: (a) selected randomly, and (b) selected through referrals from the former group based on the similarity of their interests, as they are also consumers. By distributing the questionnaires online, it helped the researcher reach a larger sample group rapidly and inexpensively. The questions were measured using a seven-point Likert scale because it provided more granularities and prevented respondents from being too neutral in their responses (Wakita, Ueshima \& Noguchi 2012). After data collection, the data 
was screened prior to analysis to achieve higher reliability and validity. Two hundred ninety (290) usable questionnaires were received; giving a response rate of $29 \%$.

\section{RESULTS}

\section{RESPONDENTS’ DEMOGRAPHIC PROFILE}

TABLE 1. Frequency distribution of the respondents

\begin{tabular}{ccc}
\hline Gender & Frequency & Percentage \\
Male & 139 & 47.9 \\
Female & 151 & 52.1 \\
Age & & \\
$\leq 25$ & 69 & 23.8 \\
$26-35$ & 157 & 54.1 \\
$36-45$ & 49 & 16.9 \\
$\geq 46$ & 15 & 5.2 \\
Ethnic group & & \\
Malay & 109 & 37.6 \\
Chinese & 113 & 39.0 \\
Indian & 64 & 22.0 \\
Other & 4 & 1.4 \\
Primary & & \\
Secondary & 9 & 3.0 \\
Diploma/ College & 26 & 9.0 \\
Graduate & 53 & 18.3 \\
Postgraduate & 171 & 59.0 \\
Monthly Income Level & 31 & 10.7 \\
$\leq$ RM 1,000 & & \\
RM 1,001-RM 3,000 & 16 & 5.5 \\
RM 3,001-RM 5,000 & 35 & 12.2 \\
RM 5,001-RM 7,000 & 46 & 15.8 \\
$\geq$ RM 7,001 & 68 & 23.4 \\
& 125 & 43.1 \\
\hline
\end{tabular}

Table 1 shows the frequency distribution of the respondents. There was unequal distribution between male and female respondents due to the use of snowballing technique during data collection. It might also been that female respondents were more willing to participate in answering the questionnaires compared to male respondents. The respondents were divided into 4 age categories, 25 years old and below, 26 - 35 years old, 36 - 45 years old and 46 years old and above. Majority of the respondents were between 26 - 35 years old (54.1\%) while the minority was 46 years old and above (5.2\%). Respondents in the age group 25 years old and below, and between 36 - 45 years old were $23.8 \%$ and $16.9 \%$ respectively. Respondents between the ages of 26 - 35 years old may be more aware and interested in CSR topics and were more willing to give responses by filling up the questionnaire. Chinese respondents made up the highest percentage of respondents (39\%), followed by Malays (37.6\%), Indian (22\%) and others (1.4\%). Chinese respondents came highest because the channels and places selected for questionnaire distribution were frequented mainly by the Chinese, despite the Malays being the largest race in Malaysia. 
A large proportion of the respondents were graduates with bachelors' degree (59\%) while a small proportion of respondents had educational background up to primary school level (3.1\%). Respondents with secondary high school level came up to $9 \%$, while $18.3 \%$ have diplomas and $10.7 \%$ have masters or a $\mathrm{PhD}$ degree. The respondents were generally well educated and able to understand the questionnaire. A small proportion $(5.5 \%)$ of respondents earned less than RM 1,000 a month. A large proportion (43.1\%) earned in the range of RM 7,001 and above. $12.2 \%$ of the respondents earned a monthly income between RM 1,001-RM $3,000,15.8 \%$ of respondents earned a monthly income between RM 3,001- RM 5,000, while $23.4 \%$ of respondents earned a monthly income between RM 5,001- RM 7,000. For those who earned less than or equal to RM 1,000, it is possible that the respondents within this income group are yet to be fully employed.

\section{RELIABILITY TEST}

Table 2 shows the reliability statistics for each variable in the questionnaire. Cronbach's alpha test was used to test for internal consistency of each statement for each construct. Nunnally (1978) stated that if the Cronbach's alpha value is greater than 0.7 , it is considered reliable, and an alpha value that is more than 0.6 is acceptable (Sekaran 2005; George \& Mallery 2008). Thus, a value greater than 0.6 signals reliability

TABLE 2. Reliability statistics

\begin{tabular}{llll}
\hline Variables & Number of Items & Number of Items deleted & $\begin{array}{l}\text { New } \\
\text { Alpha }\end{array}$ \\
\hline Economic Concerns & 5 & - & 0.732 \\
Environmental Concerns & 6 & - & 0.844 \\
Social Concerns & & - & \\
$\quad i$. Consumers & 4 & - & 0.849 \\
$\quad$ ii. Community & 5 & 1 & 0.874 \\
Legal Concerns & 5 & - & 0.785 \\
Consumers'Purchasing Behavior & 6 & & 0.868 \\
\hline
\end{tabular}

Based on Table 2, the Cronbach's alpha for the economic, environmental and social concerns are deemed reliable. However, 5 items used to measure legal concerns had a Cronbach's alpha of 0.431 , which is lower than 0.7 and thus deemed unreliable. In order to increase the reliability, one item was deleted which increased the new Cronbach's alpha for legal concern to 0.785 with 4 items measured. Lastly, the alpha coefficient of consumers' purchasing behavior from responsible companies was 0.868 . Therefore, the relationships between the items measured are considered reliable for further analysis.

\section{COMMON METHOD BIAS AND NON-RESPONSE BIAS}

Harman's single-factor test via SPSS software version 24 was performed and the findings indicated that the first factor explained $26.99 \%$ of the total variance. This shows that common method bias is not critical and does not affect the results. The Levene's values for all the constructs were insignificant based on the results of the independent t-test thus risk of nonresponse bias is non-critical.

\section{NORMALITY TEST}

The purpose of the normality test is to test whether the independent and dependent variables are normally distributed (Hair et al. 2010). Thode (2002) stated that skewness and kurtosis are commonly used in research to test the normality of the data. A perfect normal distribution has 
zero value for skewness and kurtosis. However, a basic rule of thumb is that, it is a normal distribution if the results of skewness and kurtosis tests are between -1.0 and +1.0 .

TABLE 3. Normality statistics

\begin{tabular}{ccc}
\hline Variables & Skewness & Kurtosis \\
\hline Economic Concerns & -0.284 & -0.188 \\
Environmental Concerns & -0.307 & -0.657 \\
Social Concerns & -0.423 & -0.257 \\
Legal Concerns & 0.046 & -0.796 \\
Consumers' Purchasing Behavior & 0.068 & -0.637 \\
\hline
\end{tabular}

Table 3 shows the results of the normality test of the variables, based on the measurement of skewness, and kurtosis. The purpose of the test was to determine and measure whether the data fits a normal distribution.

The results above indicate that all variables (economic concerns, environmental concerns, social concerns, legal concerns and consumers' purchasing behavior) were normally distributed (between -1.0 to +1.0 ).

\section{PEARSON CORRELATION COEFFICIENT}

The purpose here was to determine the relationship between the independent variables, and the dependent variable. Both variables were measured on the interval or ratio scale. The data for both variables must be normally distributed. Pearson Product-Moment Correlation usually has values ranging between -1.0 to +1.0 . If the value is close to -1 , this means that the two variables have a negative relationship. Meanwhile, if the value is close to +1 , this implies that the two variables are highly correlated.

TABLE 4. Pearson correlation analysis

\begin{tabular}{cccccc}
\hline & EC & EnC & SC & LC & CPB \\
\hline EC & 1 & & & & \\
EnC & $0.477^{* *}$ & 1 & 1 & & \\
SC & $0.055^{* *}$ & $0.707^{* *}$ & $0.635^{* *}$ & 1 & \\
LC & $0.545^{* *}$ & $0.613^{* *}$ & $0.620^{* *}$ & $0.616^{* *}$ & 1 \\
CPB & $0.486^{* *}$ & $0.528^{* *}$ & & & \\
\hline
\end{tabular}

Note $: \mathrm{EC}=$ Economic concerns; $\mathrm{EnC}=$ Environmental concerns; $\mathrm{SC}=$ Social concerns;

$\mathrm{LC}=$ Legal concerns; $\mathrm{CPB}=$ Consumer purchasing behavior

** Correlation is significant at the 0.05 level

Table 4 shows the relationship between the dependent variable and every single independent variable at a 5\% significance level. If the value is close to -1 , this means that the two variables are lowly correlated, and if the value is close to +1 , this implies that the two variables are highly correlated.

Consumer purchasing behavior (CPB) appeared to be significantly and positively correlated with the four independent variables, with economic concerns $(\mathrm{r}=0.486)$, environmental concerns $(r=0.528)$, social concerns $(r=0.620)$ and legal concerns $(r=0.616)$. Based on the results, the highest positively correlated was social concerns, followed by legal concerns. Environmental concerns were moderately correlated, while economic concerns had the weakest positive relationship with consumers' purchasing behavior on responsible companies. 


\section{MULTIPLE REGRESSION}

The multicollinearity test was performed and the results indicated the absence of multicollinearity for all the variables since the variance inflation factor (VIF) values for them were less than 5; and the tolerance values were within acceptable range. Multiple Regression analysis is used to examine the relationship between a dependent variable (consumers' purchasing behavior on responsible companies) and multiple variables (economic concerns, environmental concerns, social concerns, and legal concerns).

TABLE 5. ANOVA ${ }^{\mathrm{a}}$ of multiple regression

\begin{tabular}{llllll}
\hline & Sum of Squares & Df & Mean Square & F & Sig \\
\hline Regression & 106.800 & 4 & 26.700 & 64.864 & $0.000^{\mathrm{b}}$ \\
Residual & 117.314 & 285 & 0.412 & & \\
Total & 224.114 & 289 & & & \\
\hline
\end{tabular}

a. Dependent Variable: Consumers' purchasing Behavior

b. Predictors (Constant): Economic, Environmental, Social, Legal

An analysis of variance (ANOVA) is used to test whether there is any significant linear relationship between the combinations of the four CSR components with consumers' purchasing behavior. Table 5 shows that the p-value was 0.000 , and less than 0.05 , indicating that the four CSR components significantly influenced consumers' purchasing behavior.

TABLE 6. Multiple regression analysis

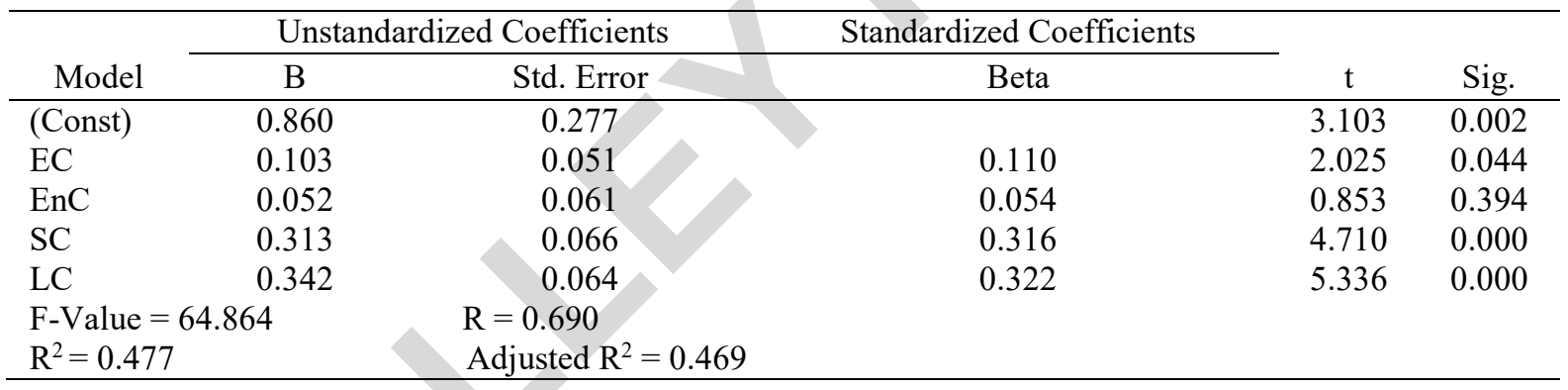

Dependent Variable: Consumers' Purchasing Behavior

Table 6 shows that the multiple $\mathrm{R}$ value was equaled to 0.690 , a positive value and it indicated that there was a positive linear relationship between economic, environmental, social and legal activities with consumers' purchasing behavior. The regression results adjusted $\mathrm{R}$ square value was 0.467. This shows that the dimensions of CSR practices collectively explained $46.7 \%$ of the variance in consumers' purchasing behavior. The F-statistic value was $(\mathrm{F}=64.864, \mathrm{p}=0.000)$, and the overall model fitted the data at a significant level of 0.05 . Three out of the four dimensions of CSR practices were significant predictors of consumers' purchasing behavior, with the beta values being legal $(\beta=0.342, p<0.05)$, social $(\beta=0.313, p$ $<0.05)$, and economic $(\beta=0.103, \mathrm{p}<0.05)$. The components are ranked following the magnitude of beta-unstandardized coefficient. Three hypotheses, $\mathrm{H}_{1 \mathrm{a}}, \mathrm{H}_{1 \mathrm{c}}$ and $\mathrm{H}_{1 \mathrm{~d}}$ are supported. The environmental dimension had a beta value of $(\beta=0.052, \mathrm{p}>0.05)$ thus insignificant in predicting consumers' purchasing behavior. Hypothesis $\mathrm{H}_{1 \mathrm{~b}}$ is not supported.

\section{DISCUSSIONS}


Economic Concerns and Consumers' Purchasing Behavior This hypothesis was supported ( $\mathrm{p}$-value $=0.044<0.05$ ). From the results obtained, Malaysian consumers ranked economic concerns as the least important. This is consistent with Maignan's (2001) study, who found that consumers rank economic concerns as the least important CSR to support. However, it is not in line with the study conducted by Safi and Ramay (2013), who stated that economic concerns are the most basic concern for corporations. Based on this, Malaysian consumers expect corporations to produce high quality goods and deliver good services that will enhance their confidence level; and these are aligned with the economic concerns of corporations. Economic concerns are important to most shareholders and employees because if the business is not profitable, there may be untold negative effects on both classes of stakeholders. One of the most significant condition or requirement for corporate existence and sustenance with respect to companies in society is economic responsibility or concern (Carroll 2016). Society expects and requires corporations to remain going concerns; but this is only possible by them being profitable in order that their shareholders are motivated to invest further while the corporations have sufficient means to sustain their operations. Society will not object to organizations making profits given that such profits are reinvested to enhance the quality of goods and services, improving the quality of life and providing more options to consumers. Trading Economics reported that Malaysian GDP (Gross Domestic Products) per capita PPP (Purchasing Power Parity) has increased from 2010 to 2016 and this trend is expected to continue. Data from the Department of Statistics Malaysia indicating a decrease in Malaysian consumers' spending in 2015, due to the implementation of the GST (Goods and Services Tax), and the weakening Ringgit. BERNAMA stated that businesses must not underestimate consumers' purchasing power by unreasonably increasing prices of goods and blaming the GST, thus, taking advantage of the increasing trend in consumers' purchasing power. Corporations cannot lose sight of the competition from various local and regional players with quality products, which give consumers more choice. The fall in the Ringgit's value to RM 4.23/ US\$1 on 24th of August 2015 (Bank Negara Malaysia 2015) has put Bank Negara, Malaysia's central bank, in a tight spot in trying to defend the Ringgit. These issues may affect confidence of foreign investors to invest here or to invest in Malaysian companies. The after effects are that the Malaysian consumers' have had to recondition their minds on spending by purchasing only necessities. Corporations must then align their economic concerns with other social and environmental concerns in order to win consumers' patronage. They must ensure that their goods and services are affordable and priced competitively.

Environmental Concerns and Consumers' Purchasing Behavior This hypothesis was not supported $(\mathrm{p}$-value $=0.394>0.05)$. This finding is in line with Dahlsrud's (2008) study who found that the environmental dimension received a significantly lower dimension ratio as compared to other dimensions. Carroll's (1999) literature review didn't include the environmental dimension in earlier definitions of CSR - which may also affect current definitions. Malaysian consumers may think that environmental concerns are not a part of overall CSR. This may be because Malaysian consumers have less awareness towards environmental pollution, recycling and waste management as compared to other developed countries (Muwazir 2011). The government has recently started to put waste management plans into action in terms of separating recyclable materials and non-recyclable materials. These initiatives may help to create more environmental awareness among Malaysian consumers. The Star Online (2015, November 14) quoted Johnson Heng, the Assistant General Manager of SCI Cabinet Industry Sdn Bhd, who said that consumers nowadays are more educated and knowledgeable. They prefer to look for $100 \%$ green products because they want the best for themselves and their family. More homeowners are becoming conscious about the materials 
that go into furniture making and are actively sourcing for environmental friendly products. Products that are not green or eco-friendly may affect consumers' purchasing behavior.

Social Concerns and the Consumers' Purchasing Behavior This hypothesis was supported ( $p$-value $=0.000<0.05$ ) and consistent with Elkington $(1997)$ who proposed that social concerns be taken into consideration. It is also in line with Bonsón and Bednárová (2013) who stated that social concerns are one of the key pillars in both the CSR and sustainability domains. From the results obtained, they ranked social concerns as second after legal concerns. Consumers perceive that it is important that business corporations have responsibilities towards their consumers and community. Malaysian consumers are likely to purchase goods or services from corporations who behave well before and after sales. They prefer to go to shops with friendly staff and a nice environment. This shows that customer services are crucial (Hanif, Hafeez \& Riaz 2010). Good customer service and friendly staff attitudes leave a positive impression on customers that can lead to customer's satisfaction and help the business retain its customers (Söderlund \& Colliander 2015). USA Today reported that, Malaysia Airlines (MAS) is one of the five airlines to receive a 5 star rating from Skytrax and won the 2013 World Travel Awards for the quality of its cabin crew, food and general excellence. Besides that, Malaysian consumers also prefer to buy goods or services from companies who always lend a helping hand to the needy. There are different ways of giving back to society such as charities (via donations, fund-raising events and corporate-sponsored programs) and social enterprises. In recent years, social enterprises in Malaysia are a nascent, growing space. Social enterprises innovate to create something different and new, and it uses a business model to sell their products or services to make it self-sustaining. Its primary purpose is to address the social impact of society such as poverty reduction or preserving the environment (Social Enterprise Malaysia 2016). The Star Online reported that Amir H. Amha, the Program Manager of MaGIC Academy (part of the Malaysia Global Innovation and Creativity Centre) and Yusuf Jaffar, Head of Social Enterprise Venture at myHarapan (a youth trust foundation) believed that social enterprises are the way forward in raising funds for long-term sustainability. Yusuf gave an example of how Batik Boutique that hires unprivileged tailors to sew its products as a source of income, which he does not think a charity, can provide. Malaysian consumers tend to support business corporations that are responsive to their customers and society.

Legal Concerns and the Consumers' Purchasing Behavior This hypothesis was supported ( $p$-value $=0.000<0.05$ ) and it is consistent with Maignan's (2001) study who found that legal concerns are the most important form of responsibility for corporations as compared to economic concerns. Malaysian consumers ranked legal concerns as the basic priority to be met. Consumers prefer products and services from corporations, which obey the rules, and regulations set up by the governing authorities. They would like to purchase safe and quality products or services, which are in accordance to safety guidelines rather than those without safety certifications. The Malaysian government introduced a new mandatory safety standard for primary batteries to protect consumers. Producers who wish to sell their primary batteries in Malaysia must have a Certificate of Conformance (COC) starting first of September 2014. They are required to make a declaration to the Malaysian Ministry of Domestic Trade, Cooperatives and Consumerism (MDTCC) stating that their products are safe, tested and conform to the prescribed safety standards for primary batteries, as well as comply with other requirements as per the relevant laws of the country. Malaysian consumers also perceive that legal concerns are very important in influencing their purchasing behavior, which includes ethical labeling of products or services. The function of ethical labeling is to incorporate ethical qualities into the product features. This promotes consumers awareness and knowhow on the critical aspect of the products that are expected to influence their purchasing decisions. 
Malaysia is a multilingual, multicultural and multiracial country; Malaysian consumers are concerned with Halal certified foods especially Muslim consumers. The Malaysian Insider reported of two Cadbury chocolate products (Cadbury Dairy Milk Hazelnut with the batch number 200813M01H I2 and Cadbury Dairy Milk Roast Almond with the batch number 221013N01R I1) being certified non-halal because they contained pig (porcine) DNA. The Health Ministry analyzed these products and they tested positive for traces of porcine DNA. Subsequent to this, the majority of Muslim consumers do not accept products that are not certified halal by the religious authority.

\section{LIMITATIONS AND AREAS FOR FURTHER RESEARCH}

There are some limitations to this study, inviting future researches. Firstly, this study only surveyed 290 respondents, thus the findings cannot be generalized to all Malaysian consumers. A bigger sample size would likely be more insightful.

Secondly, the study focused on the direct relationship between economics, social and legal concerns on consumers' purchasing behaviour. However, there may be other factors such as macroeconomics and political factors for future research.

Thirdly, the sole use of the Likert scale in assessing the items' constructs may be deficient. Thus, future study could use secondary data to verify the findings of this study and improve the researchers' ability to generalize the findings. Finally, the cultural and political dimensions of CSR need further studies especially with social-political problems that are prevalent in most societies, particularly in emerging and developing countries.

\section{IMPLICATIONS}

Managers can use the results of this research in managing their businesses. In today's business world, a single CSR strategy may not be sufficient for corporations to compete in this highly dynamic business environment. Managers should consider the mix dimensions of CSR in their strategies in order to maximize its benefits, especially in dealing with the tensions and tradeoffs between various CSR dimensions. They need to consider integrating the dimensions holistically by affirming policies, practices, decisions and actions rather than on piecemeal basis. Managers need to come up with a CSR framework that is sustainable now and in the future.

The findings might also be useful to policymakers because this study suggests an important opportunity to encourage business corporations to engage and disclose their CSR - as the findings show that the CSR components have a significant impact on consumers' purchasing behavior. This study also adds value to the literature by extending consumers' purchasing behavioral pattern in the Malaysian context to assess whether the dimensions are relevant to this particular behavior. Furthermore, academics can expand this study by looking at the cultural, political and family aspects, which can help with the development of theories and enhancement of literature.

\section{CONCLUSION}

In summary, this research serves as a source of information for the industry, especially to the management. The research findings provide information on consumers' perceptions of CSR, which in turn can affect consumers' purchasing behavior. By understanding the role of CSR and current market trends, management can manage their companies more effectively, such as designing the right marketing strategy in order to remain competitive. The research showed mixed results in that all the hypotheses were supported, except for the environmental concerns, 
thus, meeting part of the earlier objectives. In term of environmental concerns, Malaysians may still have less awareness about environmental issues despite recent government involvement in waste management plans. The results were consistent with previous studies as discussed earlier. CSR dimensions and relevant issues must be viewed and addressed as a whole rather than as fragmented parts, while the tensions and trade-offs must be viewed within the Malaysian context. Further studies on the cultural, political and family aspects of CSR need to be done that may enhance the development of new theories and their applications.

\section{ACKNOWLEDGEMENT}

The authors would like to thank the Universiti Putra Malaysia for sponsoring this research project.

\section{REFERENCES}

Al-Dmour, H.H. \& Askar, H.A. 2011. The impact of corporate social responsibility on the companies' perceived performance: A comparative study between local and foreign companies in Jordan. Journal of Business Administration 7(1): 95-115.

Amran, A. \& Nejati, M. 2014. Corporate social responsibility perception among developing country SMEs: An exploratory study of ethics, governance and corporate crime: Challenges and consequences. Developments in Corporate Governance and Responsibility 6: 85-104.

Boccia, F., Malgeri Manzo, R. \& Covino, D. 2018. Consumer behavior and corporate social responsibility: An evaluation by a choice experiment. Corporate Social Responsibility and Environmental Management 26(1): 97-105.

Bonsón, E. \& Bednárová, M. 2013. Corporate LinkedIn practices of Eurozone companies. Online Information Review 37(6): 969-984.

Butt, I. 2016. Corporate social responsibility and consumer buying behavior in emerging market: A mixed method study. International Journal of Business and Management 11(7): 211.

Carroll, A.B. 1991. The pyramid of corporate social responsibility: Toward the moral management of organizational stakeholders. Business Horizons 34(4): 39-48.

Carroll, A.B. 1999. Corporate social responsibility: Evolution of a definitional construct. Business \& Society 38(3): 268-295.

Carroll, A.B. 2016. Carroll's pyramid of CSR: Taking another look. International Journal of Corporate Social Responsibility 1(3): 1-8.

Dahlsrud, A. 2008. How corporate social responsibility is defined: An analysis of 37 definitions. Corporate Social Responsibility and Environmental Management 15(1): 1-13.

Dimaggio, P.J. \& Powell, W.W. 1983. The iron cage revisited: Institutional isomorphism and collective rationality in organizational field. American Sociological Association 48(2): 147-160.

Dusuki, A.W. \& Yusof, T.F. 2008. The pyramid of corporate social responsibility model: Empirical evidence from Malaysian stakeholder perspectives. Malaysian Accounting Review 7(2): 29-54.

Elkington, J. 1997. Cannibals with Forks: The Triple Bottom Line of 21st Century Business. Paris: Capstone/Oxford.

Fallon, N. 2014. What is corporate social responsibility? BusinessNewsDaily.com. Available at http://www.businessnewsdaily.com/4679-corporate-social-responsibility.html

Forsman-Hugg, S., Katajajuuri, J. M., Riipi, I., Mäkelä, J., Järvelä, K. \& Timonen, P. 2013. Key CSR dimensions for the food chain. British Food Journal 115(1): 30-47. 
Frooman, J. 1999. Stakeholder influence strategies. Academy of Management Review 24(2): 191-205.

Gadenne, D., Sharma, B., Kerr, D. \& Smith, T. 2011. The influence of consumers' environmental beliefs and attitudes on energy saving behaviour. Energy Policy 39(12): 7684-7694.

Galbreath, J. 2010. How does corporate social responsibility benefit firms? Evidence from Australia. European Business Review 22(4): 411-431.

Gallardo-Vázquez, D. \& Sanchez-Hernandez, M.I. 2014. Measuring corporate social responsibility for competitive success at a regional level. Journal of Cleaner Production 72: 14-22.

Gatti, L., Caruana, A. \& Snehota, I. 2012. The role of corporate social responsibility, perceived quality and corporate reputation on purchase intention: Implications for brand management. Journal of Brand Management 20(1): 65-76.

George, D. \& Mallery, P. 2008. SPSS for Windows Step by Step: A Simple Guide and Reference, Update 15.0. Boston, MA: Allyn \& Bacon.

Grimmer, M. \& Bingham, T. 2013. Company environmental performance and consumer purchase intentions. Journal of Business Research 66(10): 1945-1953.

Gupta, A. 2012. Sustainable competitive advantage in service operations: An empirical examination. J. Appl. Bus. Res. 28(4): 735-742.

Hair, J.F. Jr., Black, W.C., Babin, B.J. \& Anderson, R.E. 2010. Multivariate Data Analysis: A Global Perspective. 7th ed. Upper saddle River, NJ: Pearson.

Hanif, M., Hafeez, S. \& Riaz, A. 2010. Factors affecting customer satisfaction. International Research Journal of Finance and Economics 60(1): 44-52.

Haytko, D.L. \& Matulich, E. 2008. Green advertising and environmentally responsible consumer behaviors: Linkages examined. Journal of Management and Marketing Research 1: 2-11.

Islam, M.A. 2015. Social Compliance Accounting. Managing Legitimacy in Global Supply. Cham, Switzerland: Springer.

Kaika, D. \& Zervas, E. 2013. The Environmental Kuznets Curve (EKC) theory-Part A: Concept, causes and the CO2 emissions case. Energy Policy 62: 1392-1402.

Khare, A. 2015. Antecedents to green buying behaviour: A study on consumers in an emerging economy. Marketing Intelligence \& Planning 33(3): 309-329.

Khojastehpour, M. \& Johns, R. 2014. The effect of environmental CSR issues on corporate/brand reputation and corporate profitability. European Business Review 26(4): 330-339.

Lee, J. \& Lee, Y. 2015. The interactions of CSR, self-congruity and purchase intention among Chinese consumers. Australasian Marketing Journal (AMJ) 23(1): 19-26.

Leonidou, C.N. \& Leonidou, L.C. 2011. Research into environmental marketing/management: A bibliographic analysis. European Journal of Marketing 45(1/2): 68-103.

Lin, P.C. \& Huang, Y.H. 2012. The influence factors on choice behavior regarding green products based on the theory of consumption values. Journal of Cleaner Production 22(1): 11-18.

Maignan, I. 2001. Consumers' perceptions of corporate social responsibilities: A cross-cultural comparison. Journal of Business Ethics 30(1): 57-72.

Malaysia, B.N. 2015. Financial Stability and Payment Systems Report 2014. Bank Negara Malaysia.

Malaysia, S.E. 2016. Social enterprise business models.

Malhotra, N.K. \& Dash, S. 2011. Marketing Research: An Applied Orientation. 6th ed. NJ: Pearson Education. 
McAlister, D.T., Ferrell, O.C. \& Ferrell, L. 2003. Business \& Society: A Strategic Approach to Corporate Citizenship. Boston, MA: Houghton Mifflir Company.

McDonald, L.M. \& Rundle-Thiele, S. 2008. Corporate social responsibility and bank customer satisfaction: A research agenda. International Journal of Bank Marketing 26(3): 170-182.

Miragaia, D.A.M., Martins, C.I.N., Kluka, D.A. \& Havens, A. 2015. Corporate social responsibility, social entrepreneurship and sport programs to develop social capital at community level. International Review on Public and Nonprofit Marketing 12(2): 141154.

Moslehpour, M., Van Kien, P. \& Danyfisla, I. 2014. Differences of customer purchase behavior toward organic rice in Indonesia and Taiwan. International Journal of Quality and Service Sciences 6(4): 348-368.

Murphy, P.E., Öberseder, M. \& Laczniak, G.R. 2014. Corporate societal responsibility in marketing: Normatively broadening the concept. AMS Review 3(2): 86-102.

Muwazir, M.M. 2011. Corporate social responsibility in the context of financial services sector in Malaysia. Doctoral dissertation, Cardiff University.

Nochai, R. \& Nochai, T. 2014. The effect of dimensions of corporate social responsibility on consumers' buying behavior in Thailand: A Case Study in Bangkok. Paper presented at the International Conference on Economics, Social Sciences and Languages (ICESL'14) May 14-15, Singapore.

Nunnally, J.C. 1978. Psychometric Theory. New York: McGraw Hill.

Ong, T.S., Teh, B.H. \& Ang, Y.W. 2014. The impact of environmental improvements on the financial performance of leading companies listed in Bursa Malaysia. International Journal of Trade, Economics and Finance 5(5): 386-391.

Onlaor, W. \& Rotchanakitumnuai, S. 2010. Enhancing customer loyalty towards corporate social responsibility of Thai mobile service providers. World Academy of Science, Engineering and Technology 40(6): 41-52.

Paco, Raposo \& Filho. 2009. Identifying the green consumer: A segmentation study. Journal of Targeting, Measurement and Analysis for Marketing 17(1): 17-25.

Parsa, H.G., Lord, K.R., Putrevu, S. \& Kreeger, J. 2015. Corporate social and environmental responsibility in services: Will consumers pay for it? Journal of Retailing and Consumer Services 22: 250-260.

Patil, D.M.R. \& Sawant, P. 2014. Corporate Social Responsibility: Towards New Agenda. Abhinav International Monthly Refereed Journal of Research in Management \& Technology Corporate Social Responsibility, Performance And Sustainability Reporting of Shree Cement Company In India 3(4): 32-39.

Pomering, A. \& Dolnicar, S. 2009. Assessing the prerequisite of successful CSR implementation: Are consumers aware of CSR initiatives? Journal of Business Ethics 85(2): 285-301.

Rahbar, E. \& Wahid,N.A. 2010. The Malaysian consumer and the environment: Purchase behavior. Global Business and Management Research: An International Journal 2(4): 323-336.

Rahim, R.A., Jalaludin, F.W. \& Tajuddin, K. 2011. The importance of corporate social responsibilities on consumer behavior in Malaysia. Asian Academy of Management Journal 16(1): 119-139.

Roberts, P.W. \& Dowling, G.R. 2002. Corporate reputation and sustained superior financial performance. Strategic Management Journal 23(12): 1077-1093.

Safi, A. \& Ramay, M. 2013. corporate social responsibility and consumer behavior: A study from Pakistan. Information Management \& Business Review 5(4): 194-202.

Sekaran, U. 2005. Research Methods For Business - A Skill Building Approach. $4^{\text {th }}$ ed. New York: John Wiley and Sons. 
Sen, S., Bhattacharya, C.B. \& Korschun, D. 2006. The role of corporate social responsibility in strengthening multiple stakeholder relationships: A field experiment. Journal of the Academy of Marketing Science 34(2): 158-166.

Scholder, E.P., Webb, D.J. \& Mohr, L.A. 2006. Building corporate associations: Consumer attributions for corporate socially responsible programs. Journal of the Academy of Marketing Science 34(2): 147-57.

Söderlund, M. \& Colliander, J. 2015. Loyalty program rewards and their impact on perceived justice, customer satisfaction, and repatronize intentions. Journal of Retailing and Consumer Services 25: 47-57.

The Star Online. 2015. Nation News. Homeowners Eye Eco-friendly Products at Ongoing Exhibition. Available at http://www.thestar.com.my/news/nation/2015/11/14/green-is-inat-perfect-livin-15-homeowners-eye-ecofriendly-products-at-ongoing-exhibition/.

Thode, H.C. 2002. Testing for Normality (Vol. 164). CRC Press.

Thompson, B. \& Ke, Q. 2012. Whether environmental factors matter: Some evidence from UK property companies. Journal of Corporate Real Estate 14(1): 7-20.

Liu, M.T., Wong, I.A., Shi, G., Chu, R. \& Brock, J.L. 2014. The impact of corporate social responsibility (CSR) performance and perceived brand quality on customer-based brand preference. Journal of Services Marketing 28(3): 181-194.

Turker, D. 2009. Measuring corporate social responsibility: A scale development study. Journal of Business Ethics 85(4): 411-427.

Uddin, M.U., Hassan, M.R. \& Tarique, K.M. 2008. Three dimensional aspects of corporate social responsibility. Daffodil International University Journal of Business and Economics 3: 199-212.

Vahdati, H., Mousavi, N. \& Tajik, Z.M. 2015. The study of consumer perception on corporate social responsibility towards consumers' attitude and purchase behavior. Asian Economic and Financial Review 5(5): 831-845.

Van Birgelen, M., Semeijn, J. \& Keicher, M. 2009. Packaging and pro environmental consumption behavior. Environment and Behavior 41(1): 125-146.

Vermillion, L.J. \& J. Peart, J. 2010. Green marketing: Making sense of the situation. Journal of Business Strategy 34(6): 3-10.

Visser, W. 2005. Revisiting Carroll's CSR pyramid: An African perspective. In Corporate Citizenship in Developing Countries: New Partnership Perspectives, edited by $\mathrm{M}$. Huniche \& E. R. Pedersen, 29-56. Copenhagen: Copenhagen Business School Press.

Visser, W. 2011. The Age of Responsibility: CSR 2.0 and the New DNA of Business. London: John Wiley \& Sons.

Wakita, T., Ueshima, N. \& Noguchi, H. 2012. Psychological distance between categories in the Likert scale: Comparing different numbers of options. Educational and Psychological Measurement 72(4): 533-546.

Wong, T.N., Lee, L.H. \& Sun, Z. 2012. CSR and environmental criteria in supplier selection. In Proceedings of the Asia Pacific Industrial Engineering \& Management Systems Conference 2012. APIEMS.

Zhao, G. 2012. CSR and its impact on consumer behavior: A study of the cosmetic industry. Unpublished Masters' thesis, Jönköping University, Jönköping International Business School.

Boon Heng Teh

Faculty of Management

Multimedia University 
Persiaran Multimedia

63100 Cyberjaya, Selangor, MALAYSIA.

E-Mail: bhteh@mmu.edu.my

Tze San Ong (corresponding author)

Department of Accounting and Finance

Faculty of Economics and Management

Universiti Putra Malaysia

43400 UPM Serdang, Selangor, MALAYSIA.

E-Mail: tzesan@upm.edu.my

Lai Teng Pang

Department of Accounting and Finance

Faculty of Economics and Management

Universiti Putra Malaysia

43400 UPM Serdang, Selangor, MALAYSIA.

E-Mail: laitengphang@hotmail.com

Haslinah Muhammad

Department of Accounting and Finance

Faculty of Economics and Management

Universiti Putra Malaysia

43400 UPM Serdang, Selangor, MALAYSIA.

E-Mail: hasm@upm.edu.my

Tze Chin Ong

Inti International University

Persiaran Perdana BBN, Putra Nilai

71800 Nilai, Negeri Sembilan, MALAYSIA.

E-Mail: tzechin.ong@newinti.edu.my 